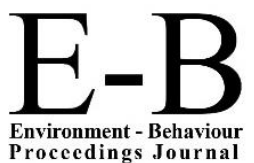

Environment - Behaviour
Procecdings Journal

\section{CSSR 2018}

https://cssr.uitm.edu.my/2018/

5th International Conference on Science and Social Research

Le Meridien Kota Kinabalu Hotel, 5 - 6 December 2018

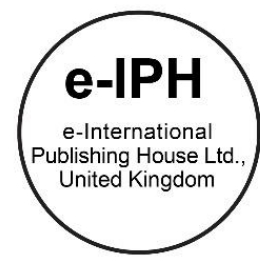

\title{
Factors Affecting Teachers Attitude towards Designing Virtual Learning Environment
}

\author{
Kumar Raman 1, Norasmah Othman 1, Haryanti Mohd Affandi², Indera Irawan Md. Rawi ${ }^{3}$ \\ ${ }^{1}$ Faculty of Education, Universiti Kebangsaan Malaysia, 43600 Bangi, Malaysia. \\ 2 Faculty of Design and Built Environment, Universiti Kebangsaan Malaysia, 43600 Bangi, Malaysia \\ ${ }^{3}$ Faculty of Design and Built Environment, First City University College, 47800 Petaling Jaya, Malaysia
}

kumarraman_71@yahoo.com; lin@ukm.edu.my; haryantima@ukm.edu.my; indera.chandran@firstcity.edu.my

Tel: 013-7494948

\begin{abstract}
In many developing countries, Information and Communication Technology had been introduced. Its integration with the curriculum is limited. In view of this, a survey was conducted to examine the factors that affect teacher's attitude in adopting virtual learning environment in their classroom teaching. The result of regression analysis revealed that Perceived usefulness and Perceived ease of use, had been seen to have more considerable significance than Social Influence and Facilitating Condition in affecting teacher's attitude to adopt Frog VLE. Together these constructs explained 57 per cent the variance in teacher's intention to use VLE application in their teaching.
\end{abstract}

Keywords: Virtual Learning Environment; ICT in teaching and learning; teacher's attitude towards e-learning

eISSN: 2398-42870 2020. The Authors. Published for AMER ABRA CE-Bs by e-International Publishing House, Ltd., UK. This is an open access article under the CC BYNC-ND license (http://creativecommons.org/licenses/by-nc-nd/4.0/). Peer-review under responsibility of AMER (Association of Malaysian Environment-Behaviour Researchers), ABRA (Association of Behavioural Researchers on Asians) and CE-Bs (Centre for Environment-Behaviour Studies), Faculty of Architecture, Planning \& Surveying, Universiti Teknologi MARA, Malaysia.

DOI: https://doi.org/10.21834/ebpj.v5iSI3.2560

\subsection{Introduction}

Information and Communication Technology (ICT) has become a major agenda in education innovation in most western countries. For example, in the United Kingdom, British Educational Communications (BECTA) has embarked on the Next Generation Learning campaign to ensure effective and innovative ICT usage in education (Chen, 2010). Meanwhile, the Malaysia Education Blue Print (2013-2025) emphasized the use of ICT in education to enhance the quality of learning to create innovative human capital (Ministry of Education Malaysia, 2012) and to drive the country from a product-based economy to a knowledge-based economy (Lai et al. 2009). Therefore, the Ministry of Education, Malaysia (MOE) confidently stated that the use of ICT in teaching and learning (T\&L) is a prerequisite for generating skillful and experienced person.

\subsection{Literature Review}

The Multimedia Super Corridor (MSC) extension in 1996 was a turning point for MOE to integrate ICT into education through various programs such as Smart School program (Nor Fadzleen Sadon et al. 2013). In this effort, MOE has invested nearly RM6 billion from the year 1999 to 2010 (Ministry of Education Malaysia, 2012). The latest initiative by MOE is the beginning of 1BestariNet which

eISSN: 2398-4287@ 2020. The Authors. Published for AMER ABRA cE-Bs by e-International Publishing House, Ltd., UK. This is an open access article under the CC BYNC-ND license (http://creativecommons.org/licenses/by-nc-nd/4.0/). Peer-review under responsibility of AMER (Association of Malaysian Environment-Behaviour Researchers), ABRA (Association of Behavioural Researchers on Asians) and cE-Bs (Centre for Environment-Behaviour Studies), Faculty of Architecture, Planning \& Surveying, Universiti Teknologi MARA, Malaysia. DOI: https://doi.org/10.21834/ebpj.v5iSI3.2560 
provides high-speed internet connection as well as access to the Integrated Learning Solutions for 10,000 schools nationwide, 500,000 teachers, 5.5 million pupils and 4.5 million parents. However, studies conducted in developing countries shows that ICT integration in education is a complex process of innovation and facing various obstacles (Kung Teck et al. 2013). In Malaysia, only one-third of teachers are using ICT in teaching and learning (T\&L) process, and most of them are using PowerPoint presentations as teaching tools (UNESCO, 2012). Furthermore, less than 80 per cent of teachers are using ICT for less than one hour per week in their classroom teaching (Ministry of Education Malaysia, 2010). Meanwhile, Malaysian Auditor General's report in 2013 was stated that the usage of Frog VLE application in T\&L by teachers and pupils were shallow, which was between 0.01 per cent to 4.69 per cent only (Ministry of Finance Malaysia, 2013; UNESCO, 2012). It shows that although various initiatives were taken to accelerate the use of ICT in T\&L the rate of consumption is still low.

Even though ICT is useful for both teachers and students still, only the teachers are able to determine the success or failure of the ICT implementation at the school level (Motaghian et al. 2013). If teachers use ICT optimally in T\&L, then the students have no reason to avoid ICT (Motaghian et al. 2013). It means, the teacher's attitude has a significant relationship with the level of acceptance and use of technology (Cakir \& Solak 2015) as well as determining the success of Frog VLE Program at the school level. In the same line with this, Davis (1989), mentioned that the behaviour intention (BI) to use technology was affected by Perceived Ease of Use (PEOU) and Perceived Usefulness (PU). Consequently, most of the acceptance and usage of technology for individuals were using the Technology Acceptance Model (TAM) (Davis, 1989; Arteaga Sanchez \& Duarte Hueros 2010). The Technology Acceptance Model (TAM) also has been used in educational research (Kung Teck et al. 2013). Therefore, the TAM, as shown in Figure 1, was considered to be suitable for this study with the addition of two variables i.e., facilitating conditions and social influence.

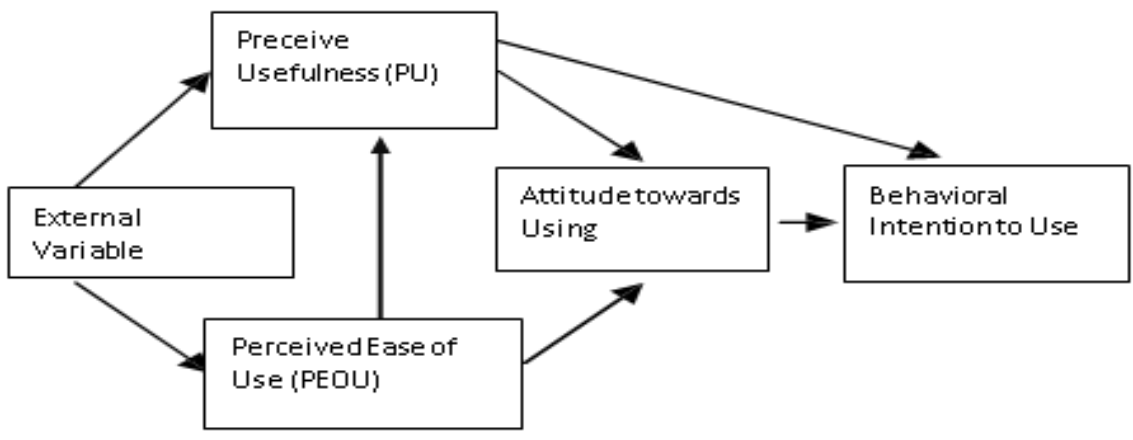

Fig. 1: Technology Acceptance Model (Davis 1989)

Perceived Ease of Use (PEOU) defined as the individual's belief of using the technology would be free of effort (Davis, 1989). Teachers like to use an easy-to-use system to avoid mistakes in their teaching. However can't jump into a conclusion that PEOU is the most critical determinant of teachers usage any method in T\&L (Sumac et al. 2011; Teo, 2011).

Perceived usefulness (PU) is the individual's belief that using technology in their work will improve their job performance (Davis et al.1989). According to Teo and Schaik (2009), PU can explain 69 per cent variance attitudes towards computer usage among preservice teachers at the National Institute of Education, Singapore. This means attitude toward computer use is determined by the use of technology in T\&L (Faud \& Sharifah, 2013).

Facilitating conditions (FC) indicates the individual's level of confidence in the organization and technical infrastructure which support the system usage. Kinley et al. (2013) stated that internet access had become an essential factor in promoting e-learning. Although e-learning can improve the quality of T\&L, but the effectiveness is depending on how the system was used by the teachers (Thornton et al. 2004). Therefore, the inefficient implementation of facilities will cause the e-learning program to be unsuccessful (Hogarth \& Dawson, 2008).

Social Influence (SI) refers to the influence on one's emotions, opinions or behaviour by others action or practices especially by somebody vital in one's life (Karahanna \& Straub, 1999). It has also been conceptualized as the subjective norm (Fishbein \& Ajzen, 1975), normative beliefs (Vijayasarathy, 2004) and social norms (Hsu \& Lu, 2004) which was initially part of Theory of Reasoned Action (TRA) (Fishbein \& Ajzen, 1975). The Social Norm (SN) is described as an individual's attitude, which was influenced by the people around (Fishbein \& Aizen, 1975). Initially, Davis (1989), omitted SN from the original TAM. Later he added in TAM2 when he realized the importance of the influence of others on individual behaviour. In schools, principals and colleagues have a significant effect on the teacher's response. For example, sharing the success stories of technology integration by teachers can increase the curiosity of their colleagues. Further by sharing resources, pedagogical practices and helping each another will have a greater chance of successful integration. 
Teacher's Attitude Towards ICT (ATT) is defined as the teacher's perception of technology in teaching. Teacher's attitude towards ICT also shows the positive or negative feelings and its effect towards their behaviour. Attitude is one of the main factors that can directly influence the behavior intention to use the technology. Several studies conducted in institutions that were well equipped with technology has revealed attitude towards technology to be an important factor influencing adoption of technology in teaching (Padilla Meléndez et al. 2013; Chokri, 2012). Below is the hypothesis based on the literature review.

H1: Perceived Ease of Use has a significant effect on attitude towards adopting Frog VLE.

H2: Perceived Usefulness has a significant effect on attitude towards adopting Frog VLE.

H3: Facilitating conditions has a significant effect on attitude towards adopting Frog VLE.

H4: Social Influence has a significant effect on attitude towards adopting Frog VLE.

Davis (1989) Technology Acceptance Model (TAM), was adopted for the research. Two additional factors, Facilitating Conditions $(\mathrm{FC})$ and Social Influence (SI) were considered besides the other two factors, Perceived Usefulness (PU) and Perceived Ease of Use (PEOU) proposed in TAM model. The extended TAM model proposed for the study is shown in Fig. 2. Therefore, it has become vital to identify the factors that influence the attitude of teachers in Frog VLE application usage. The findings of this study will explain the factors which affect teacher's attitude and assist the authorities to improve the program together to achieve the actual goals of the program (Stufflebeam. DL \& Shinkfield. AJ 2007).

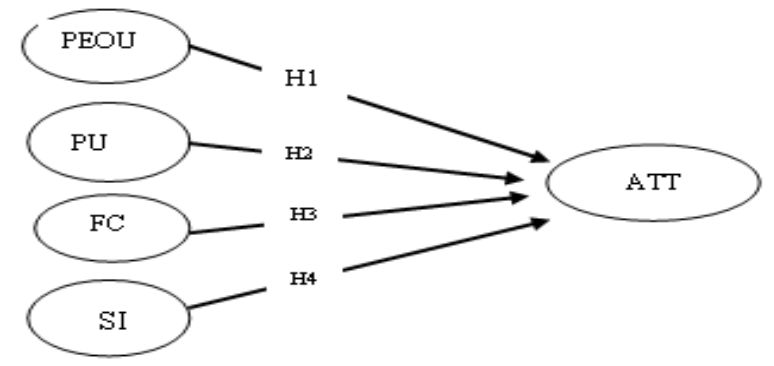

Fig. 2: Research Model

\subsection{Methodology}

\subsection{Research Design}

This study will apply surveys to collect data by using a questionnaire. The survey is commonly used in the non-experimental design which will support the external validity of the study results (Bakos \& Treacy, 1986). The survey questionnaire was split into two major sections. The first section contained a question that inquired demographic details of research participants such as their age, teaching experience, gender etc. The next section containing 32 items were Likert Scale questions. The scales ranged from 1 to 5 (5: strongly agree, 4: agree, 3: neutral, 2: disagree, 1: strongly disagree). These questions inquired the views of teachers on the factors considered for the study.

\subsection{Population and Sample}

The population is composed of all people who generalized the study and sample is a subset of the population which involved in the study (Jackson, 2003). The population of this study was 23,647 teachers from 228 secondary schools in the state of Selangor (Ministry of Education Malaysia, 2016) who have the knowledge and still using Frog VLE application in their T\&L. There are many methods and rules to determine size of the sample. The suitable and coincident sample size is between 30 to 500 respondents (Roscae, 1975). The proposed sample size was supported by Sekaran (2000), who stated that the sample size if more than 500 respondents could cause Type 1. The formula recommended by Krejcie \& Morgan (1970) and Sekaran (2000) was used in this study to determine the appropriate sample size. Table 1 shows the formula and calculation of the sample. Based on the method and calculations in Table 1 , the sample size was predetermined as 376 respondents. However, to avoid the possibility of short questionnaire or an insufficient number of returns of the questionnaire, the researcher set the sample size of the survey as 451 respondents, by increasing 20 per cent (75 respondents). Further, a simple random sampling method was used to determine the respondents of this study. However, only 430 questionnaires were received and suitable for data analysis. The overall response rate for this study was 430 teachers (95.56 per cent). The sample size was sufficient because it is more than 30 respondents which is more than 10 per cent of the population (Sekaran 2000). Then the questionnaire was analyzed using Statistical Package for Social Sciences (SPSS) version 21.

Table 1: Formula \& Sample Study Calculation of the sample

\begin{tabular}{c|c}
\hline Formula & Sample Study Calculation \\
\hline
\end{tabular}




\begin{tabular}{|c|c|}
\hline$\frac{X^{2} N P(1-P)}{s=}$ & $\frac{3.841 \times 23,647 \times 0.5(1-0.5)}{0.05 \times 0.05(23,647-1)+3.841 \times 0.5(0.5)}$ \\
\hline $\begin{array}{l}S=\text { Sample size required } \\
N=\text { Population size } \\
P=\text { The population ratio } 0.5 \\
d=\text { degree of accuracy } \\
X^{2}=\text { Chi square value at the level } \\
0.05 \text { confidence, which is } 3.841\end{array}$ & $\begin{array}{l}=\quad \underline{90828.12 .25 \times 0.25} \\
59.115+\frac{0.960}{=} \quad \frac{22707}{60.075} \\
=\quad \underline{\mathbf{3 7 6}}\end{array}$ \\
\hline
\end{tabular}

\subsection{Data analyzing}

Reliability analysis with accepted Cronbach's alpha value of 0.7 (Hair et al. 1995) to test the reliability of the questions was carried out. There were no items that were required to be eliminated since the a value for all the constructs were greater than the accepted standard reliability coefficient value, as shown in Table 2. This was followed by factor analysis to group the items under four different factors using Exploratory Factor Analysis (EFA). Seven items each were loaded into PEOU and PU, eight items were loaded into FC, and ten items were loaded into SI, as shown in Table 2. Finally, regression analysis was performed to the factors loaded to validate the hypothesis drawn for the study. Regression analysis will identify the factors which were affected the secondary school teacher's attitudes towards using Frog VLE applications in their teaching and learning process.

Table 2: Result of Reliability and Test Rotated Component Matrix

\begin{tabular}{|c|c|c|c|c|c|c|}
\hline \multirow{2}{*}{ Factor } & \multirow{2}{*}{$\begin{array}{l}\text { Item } \\
\text { Code }\end{array}$} & \multicolumn{4}{|c|}{ Component } & \multirow{2}{*}{ Cronbach' alpha (a) } \\
\hline & & 1 & 2 & 3 & 4 & \\
\hline \multirow[t]{7}{*}{ PEOU } & PEOU 2 & 0.807 & & & & \multirow{7}{*}{0.926} \\
\hline & PEOU 3 & 0.762 & & & & \\
\hline & PEOU 1 & 0.748 & & & & \\
\hline & PEOU 4 & 0.744 & & & & \\
\hline & PEOU 5 & 0.687 & & & & \\
\hline & PEOU 7 & 0.597 & & & & \\
\hline & PEOU 6 & 0.587 & & & & \\
\hline \multirow[t]{7}{*}{ PU } & PU 6 & & 0.772 & & & \multirow{7}{*}{0.930} \\
\hline & PU 5 & & 0.730 & & & \\
\hline & PU 2 & & 0.633 & & & \\
\hline & PU 7 & & 0.627 & & & \\
\hline & PU 3 & & 0.604 & & & \\
\hline & PU 4 & & 0.581 & & & \\
\hline & PU 1 & & 0.509 & & & \\
\hline \multirow[t]{8}{*}{$\mathrm{FC}$} & FC 8 & & & 0.874 & & \multirow{8}{*}{0.840} \\
\hline & FC 7 & & & 0.869 & & \\
\hline & FC 6 & & & 0.854 & & \\
\hline & FC 4 & & & 0.848 & & \\
\hline & FC 2 & & & 0.838 & & \\
\hline & FC 5 & & & 0.809 & & \\
\hline & FC 1 & & & 0.771 & & \\
\hline & FC 3 & & & 0.625 & & \\
\hline \multirow[t]{10}{*}{ SI } & SI 6 & & & & 0.800 & \multirow{10}{*}{0.925} \\
\hline & SI 5 & & & & 0.787 & \\
\hline & SI 4 & & & & 0.772 & \\
\hline & SI 7 & & & & 0.762 & \\
\hline & SI 10 & & & & 0.720 & \\
\hline & SI 3 & & & & 0.713 & \\
\hline & SI 8 & & & & 0.687 & \\
\hline & SI 2 & & & & 0.627 & \\
\hline & SI 9 & & & & 0.622 & \\
\hline & SI 1 & & & & 0.478 & \\
\hline
\end{tabular}

\subsection{Findings}

Regression analysis was applied to the factors loaded after the factor analysis. The analysis was identified factors that influence the teacher's attitude toward Frog VLE adoption in teaching. Table 3 and Table 4 were presents the result of the regression analysis. The result shows, Perceived Ease of Use (PEOU), Perceived Usefulness (PU), Social Influence (SI) and Facilitating Condition (FC) are explained $57 \%$ of variance which was significantly affecting the teacher's attitude towards the adoption of Frog VLE in classroom teaching. Out of these four factors, PU was most significant $(B=0.414, t=9.214 p<0.001)$ affects teacher's attitude to use Frog VLE, which was explained $50.5 \%$ of the variance in attitude. Therefore, hypotheses $\mathrm{H} 2$ is supported. Teachers attitude also was predicted by PEOU as ( $\beta=.233, t=5.339, p<0.001)$ whereby this variable explained $4 \%$ of the variance in attitude. As a result of this, hypotheses H1 was supported. These findings are consistent with findings in many other studies (Faud \& Sharifah, 2013; Teo, 2011; 
Davis, 1989), which found PU and PEOU have positive relation towards teacher's attitude to use technology in their teaching. It can be concluded that teachers will use technology if they perceive the technology is easy to use and using the said technology will enhance their productivity.

Apart from the above, $\mathrm{SI}(B=0.140, t=3.642, p<0.001)$ explained $1.9 \%$ and $\mathrm{FC}(\beta=0.096, t=2.847 p<0.001)$ explained $0.6 \%$ of the variance in attitude. Both $\mathrm{SI}$ and FC are also significant factors influencing the attitude of teachers for adopting Frog VLE in teaching. In view of this, hypotheses $\mathrm{H} 3$, and $\mathrm{H} 4$ were supported. A summary of hypotheses testing and regression analysis results are shown in Fig. 3.

Table 3: Result of Regression Analysis

\begin{tabular}{lllllll}
\hline Variable (X) Contribution & $\mathrm{B}$ & Beta $(\beta)$ & $\mathrm{t}$ & Sig. & $\mathrm{R} 2$ & Contribution $(\%)$ \\
\hline Perceived Usefulness (PU) & .397 & .414 & 9.214 & .000 & 0.505 & 50.5 \\
Perceived Ease of Use (PEOU), & .238 & .233 & 5.339 & .000 & 0.545 & 4.0 \\
Social Influence (SI) & .144 & .140 & 3.642 & .000 & 0.564 & 1.9 \\
Facilitating conditions (FC) & .082 & .096 & 2.847 & .005 & 0.571 & 0.6 \\
Constant & .592 & & 4.954 & .000 & & \\
\hline Multiple regression R & 0.756 & & & & & \\
R Square & 0.571 & & & & & \\
Adjusted R Square & 0.568 & & & & & \\
Standard Error & 0.39039 & & & & &
\end{tabular}

Table 4: Result of Varian Analysis

\begin{tabular}{|c|c|c|c|c|c|}
\hline Model & Sum of Squares & $\mathrm{df}$ & Mean Square & $F$ & Sig. \\
\hline $\begin{array}{l}\text { Regression } \\
\text { Residual } \\
\text { Total }\end{array}$ & $\begin{array}{l}110.469 \\
83.060 \\
193.529\end{array}$ & $\begin{array}{l}4 \\
545 \\
549\end{array}$ & $\begin{array}{l}27.617 \\
.152\end{array}$ & 181.212 & $0.001^{* *}$ \\
\hline
\end{tabular}

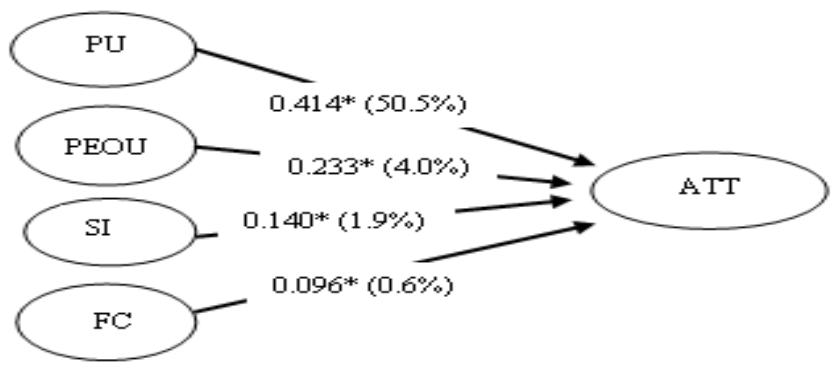

Fig 3: Results of Regression Analysis

\subsection{Discussion}

This study was confirmed that PU, PEOU, SI and FC had explained $57 \%$ of the variance which influences teacher's attitude in using technology in T\&L. The analysis result shows that PU strongly influences teacher's attitude towards technology, which explained $50.5 \%$ of the variance in teacher's attitude in using Frog VLE. These findings were consistent with some other existing research which suggested that PU and attitudes were significant determinants of teacher's intention to use technology (Teo, 2011; Lin, 2011; Macharia \& Pelser 2014). In line with this, a study conducted by Teo and Schaik (2009) among pre-service teachers at National Institute of Education in Singapore also shows that the PU variable explained $69 \%$ of the variance on attitude towards technology usage. In another word, PU has a significant relation towards the behaviour intention. Therefore, teacher's definitely will use the technology in their classroom teaching if they found the technology will be helpful and able to enhance their job performance (Davis 1998). This is similar to Davis (1989), who mentioned: "the degree to which a person believes that using a particular system would enhance his or her job performance". This was supported by Teo, (2011) who revealed that PU has played a significant role to determine the teacher's intention to use technology in classroom teaching.

The result of this study also shows that PEOU showed less variance if compared to PU. This may be because teachers gave greater importance to technology use in their teaching and to complete other clerical stuff in their daily routine. These factors could result in teachers taking a practical approach towards technology acceptance irrespective of their attitude. There is some existing research also suggested that PEOU and attitudes were significant determinants of teacher,s intention to use technology (Macharia \& Pelser 2014; Lin, 2011). However, Kathryn Mac Callum (2014), states that PEOU has a positive relationship with PU whereby the benefits of using new technology is also determined by how much effort a teacher takes to learn new technology. In the same token, if teacher's intent to use the Frog VLE application in their teaching, they must see it as an easy to use and believe that it will offer major advantages over existing methods of teaching. Thus, positive teacher's attitude towards technology will emerge once teachers are aware of the benefits of using such technology (Sherab.T \& Rinzin. D. 2016). However, previous studies also were confirmed that 
PEOU has a positive effect on the intentions of using technology (Chang \& Tung,2008; Liu et al. 2010). However, Chesney (2006) disclosed that PEOU did not have a significant influence on the intention to use the system.

Based on the literature reviewed, this context was inconsistent. Studies conducted by Landry et al. (2006) towards student's usage of Web-based learning confirmed that both PEOU and PU become the determinants for the system usage. Besides, PU was the most influential variable in the intention to use the web-based learning system in TAM (Liu et al. 2010). But according to Saeed \& Abdinnour Helm (2008) found that PU was not the most influential factor. Moreover, the literature shows that studies using TAM and models derived from TAM (Venkatesh, 2003) demonstrated that there is a relationship between PU and PEOU and behavioural intention in the acceptance and adoption of the technology. In addition, the training on technology plays an important role to influence teacher's attitude to use technology in their teaching in an efficient manner. The teachers will facing difficulty and lack of confidence and show negative reaction if they lack training.

Meanwhile, SI will easily affect one's attitude. The positive stance and the inherent nature of new technology-led them to use the technology easily without thinking of the benefits of the technology. The influence of colleagues also plays a role in influencing the attitude of teachers towards technology. Although initially, teachers are not interested in using new technology but the influence of peer-to-peer forces teachers to use them. There was some inconsistency in the literature about the influence of SI on the intention to use the technology. For example, many researchers found a significant impact of SI on behaviour intention (Venkatesh, 2003) while some researchers are failed to found any impact (M. T. Dishaw \& D. M. Strong, 1999). In this study, FC only contributes about $0.6 \%$ of the attitude of teachers who are using new technology. In other words, FC has a weak positive relationship with teacher's attitude compared to other predictors such as PU, PEOU and SI. This is because policy and distribution of financial allocations to implement ICT on education have shown positive impact. However, the findings of this study were not in line with the results of the study Norazilawati et al. (2013) who stated that school infrastructure can influence teacher attitude of using Frog VLE in T\&L process. According to Norazilawati et al. most rural schools still face problems associated with school physical infrastructure and Internet access problems that develop negative attitudes among teachers to integrate Frog VLE in T\&L. This was supported by Ouma, (2013), who states that constraints of digital facilities are an essential obstacle to the implementation of e-learning in schools.

\subsection{Conclusions and Recommendations}

The selected determinants used in this study disable to reflect the overall intentions to use Frog VLE application among teachers. The total variance stated that the attitude was only $57 \%$, and another $43 \%$ become unexplained. In view of this, future studies need to focus on other aspects such as knowledge, ability to use and motivation among teachers to answer other variances that influence the attitude of teachers to use Frog VLE. Meanwhile, the rapidly expanding technology requires replication research to update and provide appropriate knowledge and skills for teachers.

\section{References}

Arteaga Sanchez \& Duarte Hueros (2010). Motivational factors that influence the acceptance of Moodle using TAM. Computers in Human Behavior. 26, $1632-1640$.

Bakos \& Treacy (1986). Information technology and corporate strategy: A research perspective, MIS Quarterly,107-119.

Cakır \& Solak. (2015). Attitude of Turkish EFL learners towards e-learning through TAM Model. Procedia-Social and Behavioral Sciences, $176,596-601$.

Chen. (2010). Investigating models for preservice teachers' use of technology to support student-centered learning. Journal of Research on Computing in Education, $55(1), 32-42$

Chesney, T. (2006). An acceptance model for useful and fun information systems. Human Technology: An Interdisciplinary Journal on Humans in ICT Environments.

Chokri, B. (2012). Factors influencing the adoption of the e-learning technology in teaching and learning by students of a university class. European Scientific Journal, ESJ, 8(28).

Davis, F. D. (1989). Perceived usefulness, perceived ease of use and user acceptance of information technology. MIS Quartely, 13(3), 319-340.

Faud \& Sharifah (2013). Attitude Towards the Use of Learning Management System Among University Students: A Case Study. Turkish Online Journal of Distance Education, 14 (3).

Hsu, C. L., \& Lu, H. P. (2004). Why do people play on-line games? An extended TAM with social influences and flow experience. Information \& Management, 41, 853868.

Hair Jr, J. F., Anderson, R. E., Tatham, R. L., \& William, C, Black (1995), Multivariate data analysis with readings. New Jersy: Prentice Hall.

Hogarth, K., \& Dawson, D. (2008). Implementing e-learning in organizations: What e-learning research can learn from instructional technology (IT) and organizational studies (OS) innovation studies. International Journal on E- Learning, 7(1), 87-105.

Jackson, S. L. (2003). Research methods and statistics. A critical thinking approach. Belmont: Wadsworth.

K. A. Saeed \& S. Abdinnour-Helm. (2008). Examining the effects of information system characteristics and perceived usefulness on post adoption usage of information systems. Information \& Management, 45(6), 376-386. 
Karahanna, E., \& Straub, D. W. (1999). The psychological origins of perceived usefulness and ease of use. Information \&Management, 35, 237-250.

Kathryn, M. C., Lynn. J. Kinshuk. (2014). Factors Impacting Teacher's Adoption of Mobile Learning. Journal of Information Technology Education: Research, 13, $141-162$

Kinley, K., Zander, P. O., \& Georgsen, M. (2013). The usage of ICT for teaching at a Bhutanese college. In International Technology, Education and Development Conference (pp. 4126-4135). International Association of Technology, Education and Development.

Krejcie, R. V., \& Morgan, D. W. (1970). Determining sample size for research activities. Educational and psychological measurement, 30(3), 607-610.

Kung Teck, Wong, Rosma Osman, Pauline Swee Choo, Goh \& Mohd Khairezan Rahmat (2013). Understanding Student Teachers' Behavioural Intention to Use Technology: Technology Acceptance Model (TAM) Validation and Testing. International Journal of Instruction,6(1), 89-104.

Lai, J. Y., Wang, C. T., \& Chou, C. Y. (2009). How knowledge map fit and personalization affect success of KMS in high-tech firms. Technovation, 29(4), 313-324.

Landry, Griffeth, and Hartman. (2006). Measuring student perceptions of blackboard using the technology acceptance model. Decision Sciences Journal of Innovative Education, 4(1), 87-99.

Lin, K. (2011). E-learning continuance intention: Moderating effects of user e-learning experience. Computer \& Education. 56(2), 515-526.

Liu et al. (2010). Extending the TAM model to explore the factors that affect Intention to Use an Online Learning Community. Computers \& Education, 54(2), 600-610.

M. T. Dishaw \& D. M. Strong, (1999). Extending the technology acceptance model with task-technology fit constructs. Information \& Management, 36(1), 9-21.

Macharia, J. K., \& Pelser, T. G. (2014). Key factors that influence the diffusion and infusion of information and communication technologies in Kenyan higher education. Studies in Higher Education, 39(4), 695-709.

Ministry of Education Malaysia. (2016). Perangkaan Pendidikan Malaysia.

Ministry of Education, Malaysia. (2012). Malaysia Education Blueprint 2013-2025. Putrajaya: Ministry of Education Malaysia.

Ministry of Finance Malaysia. (2013). Buku Maklum Balas Ke Atas Laporan Ketua Audit Negara Mengenai Penyata Kewangan Dan Pengurusan Kewangan Tahun 2013 Siri 3.

Motaghian, Hassanzadeh, \& Moghadam, (2013). Factors affecting university instructors' adoption of web-based learning systems: Case study of Iran. Computers \& Education, 61,158-167.

Nor Fadzleen Sa'Don, Halina Mohamed Dahlan \& Haliza Zainal. (2013). Derivation for design of Virtual Learning Environment (VLE) framework for Malaysian schools. 3rd International Conference on Research and Innovation in Information Systems, ICRIIS, (November), 570-575.

Norazilawati Abdullah, Noraini Mohd Noh, Nik Azmah Nik Yusuf, (2013). Aplikasi Persekitaran Pengajaran Maya (Frog VLE) Dalam Kalangan Guru Sains. 7th International Malaysian Education Technology Convention (IMETC).

Ouma, G. O., Awuor, F. M., \& Kyambo, B. (2013). Evaluation of E-Learning Readiness in Secondary Schools in Kenya. World Applied Programming, 3(10), 493-503.

Padilla-Meléndez, A., Del Aguila-Obra, A. R., \& Garrido-Moreno, A. (2013). Perceived playfulness, gender differences and technology acceptance model in a blended learning scenario. Computers \& Education, 63, 306-317.

Roscae, (1975). Fundamental research statistics for the behavioral sciences. New York: Prentice Hall.

S. C. Chang \& Tung. (2008). An empirical investigation of students' behavioural intentions to use the online learning course websites. British Journal of Educational Technology, 39(1)71-83

Sekaran (2000). Research methods for business: A skill-building approach. New York: John Wiley \& Sons.

Sherab.T \& Rinzin. D. (2016). Factors affecting bhutanese teachers' attitude towards acceptance of technology in teaching. Journal of Bhutan Studies, 35, 82-95

Stufflebeam DL, Shinkfield AJ. (2007). Evaluation Theory, Models, and Applications. Jossey-Bass, San Francisco, CA.

Sumak, B., Hericko, M., Pusnik, M., \& Polancic, G. (2011). Factors affecting acceptance and use of Moodle: an empirical study based on TAM. Slovenian Society Informatika, 35(1), 91-100.

Teo, T. (2011). Factors influencing teachers' intention to use technology: Model development and test. Computers \& Education, 57(4), 2432-2440.

Teo, T., \& Schaik, P.V. (2009). Understanding technology acceptance in pre-service teachers: A structural equation modelling approach. The Asia Pacific Education Research, 18(1), 47-66.

Thornton, M. E., Jefferies, A., Jones, I., Alltree, J., \& Leinonen, E. (2004). Changing pedagogy: Does the introduction of networked learning have an impact on teaching In Procs 4th Int. Conf. on Networked Learning, Symp.

UNESCO, (2012). The Malaysia Education Policy Review.

Venkatesh (2003). User acceptance of information technology: Toward a unified view. MIS Quarterly, 425-478. 